DEMOCRATIC GOVERNMENT AND POLITICS 


\section{CANADIAN GOVERNMENT SERIES}

R. MacG. Dawson, Editor

1. Democratic Government and Politics. By J. A. Corry

2. The Government of Canada. By R. MAGGregor Dawson

3. Constitutional Amendment in Canada. By Paul Gérin-Lajore

4. The Canadian House of Commons: Representation. By Norman WARD

5. The Government of Prince Edward Island. By Frank MacKinnon

6. Canadian Municipal Government. By Kenneth Grant Crawford

7. Pioneer Public Service: An Administrative History of the United Canadas, 1841-1867. By J. E. Hodgetrs

8. The Government of Nova Scotia. By J. MURray BEGK

9. The Office of Lieutenant-Governor. By John T. SAYwelL 


\title{
Democratic Government and Politics
}

\author{
BY \\ J. A. CORRY \\ Hardy Professor of Political Science \\ Queen's University, Kingston \\ AND \\ J. E. HODGETTS \\ Professor of Political Science \\ Queen's University, Kingston
}

THIRD EDITION, REVISED

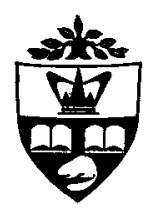

TORONTO

U N I VER S I T Y OF TORONTO PRES S 
Copyright (C), Canada, 1946, 1951

University of Toronto Press

Printed in Canada

London: Geoffrey Cumberlege

Oxford University Press

First printed, 1946

Reprinted, 1947

Reprinted, 1950

Second Edition, Revised and Enlarged, 1951

Reprinted, 1952

Reprinted, 1954

Reprinted, 1955

Reprinted, 1957

Reprinted, 1958 (twice)

Third Edition, Revised, 1959 